\title{
Physical Activity of Elementary School Pupils at a Traditional State School and a Jena Plan School
}

\section{Dita Culková, Veronika Procházková, Jan Suk}

\begin{abstract}
The study discusses physical activity concerning pupils of elementary school age at a traditional state school and an alternative school utilizing Jena plan. Their physical activity is measured by mechanical pedometers and is followed by in-depth interviews. The monitored group consists of third and fifth graders at selected schools. The research has indicated and analysed students' physical activity based on their age, gender and the type of school.
\end{abstract}

Keywords: movement activity, elementary school age, traditional pedagogy, alternative pedagogy, Jena plan, pedometer.

\section{Fyzická aktivita žáků základních škol na tradiční státní škole a na jenské škole}

\section{Abstrakt}

Studie se zabývá fyzickou aktivitou žáků základního věku na tradiční státní škole a alternativní školou využívající Jenský plán. Jejich fyzická aktivita je měřena mechanickými krokoměry a následně hloubkovými rozhovory. Sledované skupiny tvoří žáci třetí a páté 
třídy na vybraných školách. Výzkum ukázal a analyzoval fyzickou aktivitu studentů na základě jejich věku, pohlaví a typu školy.

Klíčová slova: pohybová aktivita, základní škola, tradiční pedagogika, alternativní pedagogika, Jenský plán, krokoměr.

DOI: $10.5507 /$ epd.2020.007

\section{Introduction}

Physical activity is an inseparable component of everyday human life. Movement helps to maintain physical, spiritual and psychosocial balance of the body (Blahutková, Pacholík, Póč, Hrnčiříková, \& Smolka, 2008; Sigmund, \& Sigmundová, 2015). Movement is vital and most natural presupposition to optimal promotion and physiological reinforcement of organism's functions. Physical activity enhances fitness, decreases cholesterol level, contributes to spiritual freshness, increases mental peace and stress resistance; it further promotes blood and air circulations of the brain, prevents back ache, strengthens bones reducing thus fracture risk. Furthermore, movement improves blood circulation in skin, hence its physical appearance, and finally acts as a prevention of chronical non-infective (i.e. civilizational) illnesses (Machová, \& Kubátová, 2009). According to Kalman, Hamřík and Pavelka (2009), regular and appropriate level of physical activity provides a series of positive benefits. These are e.g. cheerful mood, better pain tolerance, feelings of relaxation or happiness, ability to think better and longer, memory improvement, various stress resistance, or self-confidence boost. Tröndle (2008) affirms that movement improves overall perception of our own body.

Physical activity of children and young adults national report (2018) concludes:

- Not even a third of Czech children and young adults perform sufficiently amount of physical activity (i.e. 60 minutes daily).

- There is an increase in sedentary behaviour among Czech young adults connected with computer and mobile phone related activities.

- Nearly $80 \%$ of young adults spend their free time by watching TV or playing video games.

- School environment has a significant influence on children's and young adult's behaviour.

The recommended amount of physical activity promoting health is at least 60 minutes a day. However, this activity does not need to be performed continuously; the activity can be divided into several shorter phases. During compulsory school attendance, Physical Education (hereafter P.E.) lessons, break, sport or spontaneous games are suit- 
able for physical activities. These activities should be executed at moderate or high intensity levels (Sigmund, \& Sigmundová, 2011). School physical activity also include e. g. walking down corridors, transfers among classrooms, the canteen or the gym, walks, etc. Ideally, utilizing all abovementioned activities, students' physical activity can total 60 minutes excluding actual P.E. lessons (Mužík, \& Vlček, 2010).

The commencement of compulsory school attendance has a great impact on children's movement. Two months after their school attendance commencement children's physical activity rapidly decreases, which is a seminal life change (Mužík, \&Vlček, 2010), which can exercise significant influence on the entire educational process.

Schools nowadays approach the issue of movement inclusion in their curricula in various ways. Their attitude frequently differs depending on the type of school, their particular conditions or teachers' personality. Types of schools represent the entire scale from traditional to alternative ones. Both types are rooted in different principles. The present study discusses the issue of physical activity both at a standard as well as an alternative school utilizing Jena plan. The traditional school is represented by a school with fixed time table consisting of individual subjects; also the layout of desks is frontal with desks occupying mostly the majority of classroom space preventing pupils' free movement around the classroom. Frontal teaching predominates; students raise hands and follow teachers' instructions. The evaluation is based on marks where knowledge of facts prevails.

The alternative school monitored utilizes Jena plan. Jena plan schools predominate in the Netherlands, Belgium or Germany, with the first school founded in 1924 in Jena (Rýdl, 2001). Jena plan schools accentuate attitudes and values to be followed by skills and knowledge. In practice they do not employ fixed time table, but rather a rhythmical week working plan whose temporal boundaries can be changed during activities. The weekly plan contains activities such as work, dialogue, game or celebration. Weekly plans vary: they can be focused on individual work with both obligatory and voluntary tasks, or group (project-based) work, or conducted as a lecture. Weekly plans include free work when students may freely choose their tasks (Rýdl, 2001). As Jůva and Svobodová (1996) demonstrate, students have considerable amount of freedom hence Jena plan schools must enable free movement of students. Freedom of movement allows students to work on a carpet, or utilize desks, chairs and other furniture. Classrooms do not contain desks, but rather islands of tables and chair which can be freely moved and adjusted accordingly. Furthermore, students do not have homework and receive spoken evaluation.

Innovative and new methods developed and verified at alternative schools are frequently incorporated in standard school curricula. However, it cannot be proven that this transfer of innovative methods always comes from alternative schools. Sometimes the transfer is impossible due to a higher amount of pupils in standard classes than at alternative schools. (Průcha, 2012). 
Regardless limitations and benefits of both monitored school types, physical activity is an important component of a school day. Available researches concerning physical activity monitoring among pupils of various school types, including alternative ones, are to a great degree focused on secondary schools; furthermore, physical education is more frequently monitored as a subject, not physical activity during a school day. Related findings are presented e.g. by Haapala (2017), who notes positive changes in physical activity during a school day as a consequence of the possibility to choose a particular physical activity. Findings by Sobo (2013) identify that Waldorf schools support the incorporation of physical activity directly into classroom-based lessons rather than saving it for breaks. Another related research (Kenyon, Kubik, Davey, Sirard, \& Fulkerson, 2012) emphasizes that broader environment may have greater impact on moderate-to-vigorous physical activity than individual-level psycho-social factors. All the mentioned researches indicate that certain factors influencing physical activity at variously focused schools exist; however, the question is to what extent and in which quality they are manifested.

The present study hence is dedicated to the measure of physical activity in dependence on the school type. The aim of the present study is to outline and analyse physical activity of elementary school pupils at standard and Jena plan schools.

Research questions:

1. What is the difference in pupils' physical activity measure of between a traditional state elementary school and a Jena plan school?

2. What are the differences in physical activity between third and fifth graders at selected elementary schools?

3. How is physical activity evaluated by teachers as educational process participants?

\section{Methodology}

The methods used are mixed; the major method used was a quantitative research complemented by a qualitative method clarifying selected phenomena.

\section{Research file - quantitative part}

The research was conducted at two elementary schools in a regional town from 3. 12. to 21. 12. 2018. The research sample consisted of pupils of the third and fifth grade, aged 8-9, 10-11years respectively, whose age is ontogenetically characterized as early-school age. The research included 46 pupils: 22 girls and 24 boys; 22 traditional state school pupils and 24 alternative school pupils. The traditional state school pupils consisted of 11 girls and 11 boys; the alternative school pupils of 12 girls and 12 boys. 


\section{Research file - qualitative part}

The qualitative parts featured four females - four class teachers of third and fifth grades. Their age was between 29 to 52 . They were all subjected to an in-depth interview.

\section{Data obtaining methods}

Pupils' parents received agreements to be signed explaining the main aim of the research. Parents were provided with instructional YouTube video clarifying in detail both the research and the used pedometers handling. The research was conducted anonymously.

\section{Quantitative part data collection - measurement devices used}

Mechanical pedometers were selected from several reasons, mainly for practicality and financial accessibility. Pedometer is a simple device measuring steps. The research utilized Yamax Digiwalker SW-700 pedometer which operates on the basis of horizontally suspended spring pendulum which moves up and down during vertical waist movement. The movement of pendulum activates and deactivates electric circuit thereby counting steps (Crouter, Schneider, Karabulut, \& Bassett, 2003).

Digital display including buttons is protected by a plastic cover to avoid unwanted data erasure whilst in use. The pedometer also features a security belt with a waist clip. The display shows total amount of steps taken. The overall operation of the pedometer is simple. The data obtained from its measurement are vast and useful.

The pupils confirming their participation in the research obtained pedometers and worn them for the duration of three weeks ( 15 working days). Pedometers were distributed three days prior to the research commencement, so that pupils could familiarize with their functionality. The pedometers were worn on the right waist part secured by the clip. Pupils recorded their number of steps at the end of schooldays in designated record charts.

\section{Data processing methods}

Given the lower $n$, quantitative data were processed via nonparametric test of median values Mann-Whitney with their substantive significance monitored (Effect size). To assess the substantive significance Cohen's $d$ was utilized indicating values to assess the influence of monitored influence against the significance of other factors' significance. Furthermore, z-score was calculated.

\section{Qualitative part data collection}

Conducted interviews utilized methods of semi-structured interview. There was a list of questions from which particular ones were selected during each interview. Interviews 
were conducted at schools and audio recorded on a smart phone. Each respondent underwent open interview which was later transcribed, coded and analysed.

\section{Results}

It has been discovered that students at the Jena plan school had slightly higher level of movement activity than students at the state school. At the state school, the average number of steps taken per child was 6021 , whereas at the alternative school the result amounted to 6500 . The difference in physical activity measure thus equals 479 steps.

The use of Mann-Whitney test indicates that the significance level of 0.05 difference is not statistically substantial. The $U$-value is 38. The critical value of $U$ at $p<.05$ is 20. Therefore, the result is not significant at $p<.05$. Equally so, Cohen's $d$ indicates low significance: Cohen's $d=(6597-6103) / 2374.88=0.208011$.

Physical activity of children and young adults national report (2018) indicates that boys are more physically active than girls. Our research has confirmed these results, since at both monitored schools the average daily number of steps taken by boys was higher than of girls. Girls had balanced number of steps at both schools. The state school female students "walked" 6070, whereas at alternative schools they took 6121 steps, which is not a significant difference. The $U$-value is 38 . The critical value of $U$ at $p<.05$ is 20. Therefore, the result is not significant at $p<.05$. Cohen's $d=(6021-6070) / 2208.13=$ 0.02 , meaning Cohen's $d$ does not indicate any substantive significance.

Alternative school male pupils took 7116 steps, while boys at the state school only 6128. While using nonparametric Mann-Whitney test, a statistically significant difference among the boys is apparent. The $U$-value is 18 . The critical value of $U$ at $p<.05$ is 31 . Therefore, the result is significant at $p<.05$. Cohen's $d=(7308-6128) / 2416.47=0.49$, therefore Cohen's $d$ indicates small and medium influence of the monitored factor. The highest substantive significance was monitored among fifth grader boys at the monitored schools: Cohen's $d=(6942-5324) / 2104.40=0.77$. Therefore, from the perspective of substantive significance, the monitored factor influence is from medium to large.

The boys at the alternative school were the most active ones from the monitored groups. Differentiation between gender and school types is depicted in Figure 1. 
Fig. 1

Gender physical activity comparison at selected schools

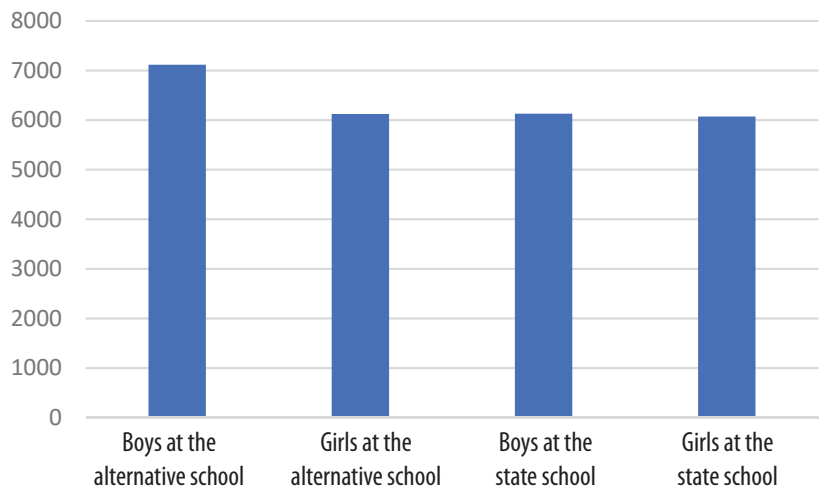

At both schools more active were third graders than fifth graders (Figure 2).

Both types of schools showed a significant difference. The $z$-score of the Jena plan school students is -4.24119 . The $p$-value is $<.00001$. The result is significant at $p<.05$. The $z$-score of the traditional school students is 2.46196 . The $p$-value is .00695 . The result is significant at $p<.05$. In both cases substantive significance and Cohen's $d$ indicate low influence of the monitored variable. Cohen's $d$ for the Jena plan school is 0.45 , while for the traditional school it is 0.34 .

Fig. 2

Average steps of third and fifth graders at individual schools

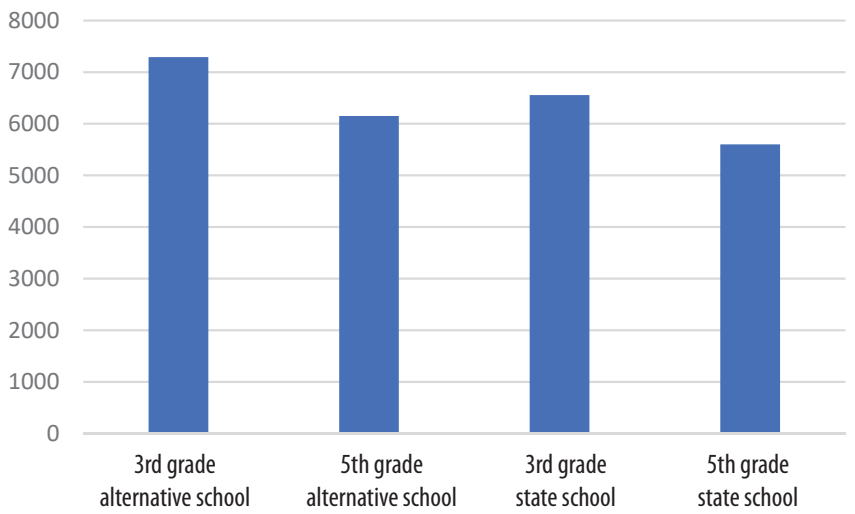


While monitoring marginal values it has been discovered that both lowest and highest average number of steps was of alternative school pupils (Figure 3 ).

Fig. 3

Lowest and highest average steps difference at selected schools

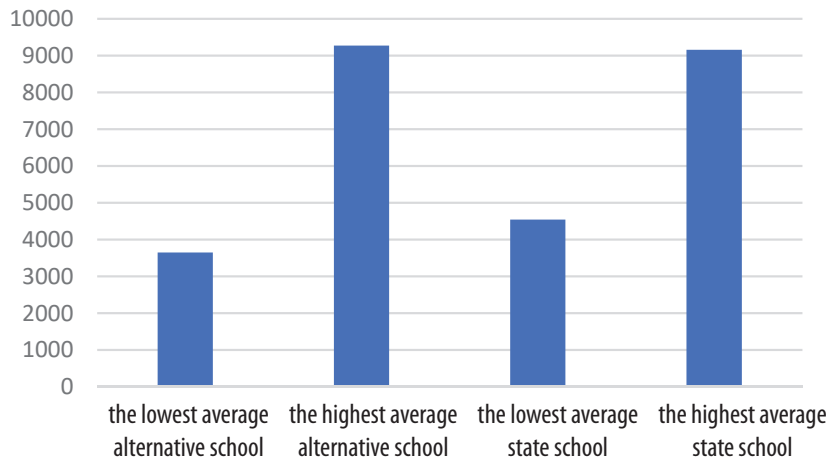

The in-depth interviews resulted in five conclusions related to monitored groups:

1. Higher amount of steps at the Jena plan school seem to be the result of educational system.

2. The alternative school pupils are devoted to more physical activities.

3. The Jena plan school pays more attention and provides more space to the development of children's independence. More active pupils thus may seek more physical activities; less active students work independently in calm. The traditional school offers less space for free movement, therefore individual children's movement average does not differ so much as at the alternative school.

4. Teacher's approach, their motivation and educational methods exercise a significant influence on physical activity.

5. All respondents are trying to implement organizational forms supporting physical activities in their lessons.

Teachers, as educational process participants, consider movement to be a seminal activity, therefore they try to employ movement enhancing organizational activities. Yet, there is an apparent difference between the traditional and Jena plan schools. Significant factors influencing this are the school type, educational methods and instructional forms. 


\section{Discussion and conclusion}

Answers to the research questions are as follows:

RQ1: What is the difference in physical activity measure between a traditional state elementary school and a Jena plan school? The monitored Jena plan school has shown greater amount of physical activity than at the monitored traditional state school. The average daily step count per child at a state school equalled 6021 , respectively 6500 at the Jena plan school. The difference in physical activity volume is thus 479 steps, which is not statistically significant difference. However, statistically significant difference was discovered among boys at both monitored schools. Statistically, the boys at the monitored Jena plan school perform significantly more steps than the boys at the monitored traditional school. The average daily step count of boys at the alternative school equalled 7116 steps, while the boys at the state school 6128 steps.

RQ2: What are the differences in physical activity between third and fifth graders at selected elementary schools? Third graders at both schools moved statistically more significantly than fifth graders, which is in accordance with researches indicating that with rising children's age the amount of their physical activity time is decreasing (Bláha, \& Cihlář, 2010).

Physical activity of children and young adults national report (2018) confirms that boys are more active than girls, which our research results confirm.

The Jena plan school showed a difference between the third and fifth grade average 1140 steps daily, whereas at the state school the difference amounted to 957 steps per day. Smaller differences among pupils, be it the third and fifth grade, or between the highest and lowest average at the state school, correspond with the following plausible explanation: the type of school with its teaching conception and educational forms and methods may influence the amount of students' physical activity. Frontal teaching predominates at the monitored standard state school. Children have thus less space for free movement inside, outside or during classes. The monitored Jena plan accentuates freedom of movement and the development of independence, a philosophy which probably results in higher physical activity of the monitored pupils as opposed to the traditional school; furthermore, this may be the reason for greater individual differences among monitored children. Another factor influencing the amount of physical activity is the teacher, their organizational forms and didactic styles. This factor, however, is closely linked with the school type and consequently their individual conditions.

Frömel (1999), Sigmund, Sigmundová (2011), Mužík and Vlček (Mužík, \& Vlček, 2010) among many recommend the amount of physical activity promoting health minimally 60 minutes per day. In 1999 the Czech Republic introduced the proposal of physical activity among children and young adults the following values: 13000 steps a day for boys and 11000 steps for girls aged 6 - 15 years (Frömel, 1999). This proposal is in accordance 
with the recommendation for adolescents as quoted in Sigmund a Sigmundová (2011); fairly similar numbers are advocated by Tudor-Locke et al. (2011), recommending for children aged 6-11 from 12000 to 16000 steps for boys and 10 000-13 000 steps for girls. If we are to apply the recommended daily amount of 13000 steps for boys and 11000 steps for girls, the results described in the present study are the following: physical activity of girls at the monitored state school equals $55,2 \%$ of the daily optimum; girls at the alternative school $55,7 \%$ of their daily optimum. Boys at the monitored traditional school amounted to $47,1 \%$ of their daily optimum, and at the Jena plan school the result was $54,7 \%$ of the daily optimum.

Because the movement activity was monitored only while being at school, leaving afternoon and evening students' activities not monitored, it is not possible to draw conclusions if the recommended daily step count was met or not. Tudor-Lock et al (2006) claims that after-school PA represents approximately half of children's daily total PA, regardless of the child's gender. Analogously, Cox, Schofield, Greasley and Kolt (2006) in their research demonstrate that steps taken out of school made up $52.4 \%$ of total daily steps. If we are to compare our findings with those of Tudor-Locke et al. (2006) and Cox et al. (2006), it can be argued that the traditional school pupils demonstrate comparable values, while the Jena plan school pupils demonstrate perceptual higher daily step count than the aforementioned research results, which appears satisfactory. $\mathrm{RQ3}$ : How is physical activity evaluated by teachers as educational process participants? According to the interviewed teachers, the greatest influence affecting physical activity is the teacher's approach and motivation of pupils. A significant factor is their choice of teaching methods and forms, which are, however, partly given by the school type and other conditions, such as the number of pupils, timetable structure, or cooperation with other teachers. As mentioned above, the Jena plan school provides a space for frequent rearrangement so pupils' movement around class is free (Svobodová, 2007). A similar approach is demonstrated by Sobo (2013) in case of Waldorf schools, accentuating physical activity incorporation into classroom-based lessons rather than allocating it for breaks or Physical Education lessons. On the contrary, the monitored traditional school does not usually allow pupils' free movement around class. Children mostly sit at desks and it educational methods and forms used are influenced either by teacher's choice or particular conditions.

The present study provides insight into selected schools and concludes that monitored Jena plan pupils show a greater volume of physical activity than monitored state school pupils. The study further demonstrates that monitored Jena plan school enables greater individual differentiation in physical activity among students. This may correlate with the findings by Haapala (2017), highlighting positive changes of physical activity during a school-day as a consequence of a partial physical activity individual choice.

Principal factors identified in the realized research which refer to a possible influence of the physical activity amount are the school type, teacher's personality, conditions, chosen organizational forms and didactic styles. 
Physical activity is one of the most natural human activities with a significant influence concerning individual's health. The amount of physical activity during classes and time spent at school can be influenced to contribute to the formation of pupils' healthy lifestyle.

\section{References}

Bláha, L., \& Cihlář, D. (2010). Uplatňování chůze u osob se zrakovým postižením. Aplikované pohybové aktivity v teorii a praxi, 2(2), 31-35.

Bláha, L., \& Cihlář, D. (2010). Uplatňování volnočasových pohybový aktivit a inaktivit u dětí na druhém stupni ZŠ. Česká kinantropologie, 4(2), 107-118.

Blahutková, M., Pacholík, V., Póč, V., Hrnčirííková, I., \& Smolka, O. (2008). Zvedni se a běž. Brno: Fakulta sportovních studií.

Cox, M., Schofield, G., Greasley, N., \& Kolt, G. (2006). Pedometer steps in primary school-aged children: A comparison of school-based and out-of-school activity. Journal of Science and Medicine in Sport, 9 (1), 91-97.

Crouter, S. E., Schneider, P. L., Karabulut, M., \& Bassett, D. (2003). Validity of 10 Electronic Pedometers for Measuring Steps, Distance, and Energy Cost. Medicine \& Science in Sports \& Exercise 35(8). 1455-60.

Kolár̆, J., Nehyba, J., \& Lazarová, B. (2011). Osobnostně sociální rozvoj - o významu pojmu optikou pedagogického diskursu. In T. Janík, P. Knecht, \& S. Šebestová, Konference České asociace pedagogického výzkumu (s. 349-355). Brno: Masarykova univerzita.

Frömel, K., Novosad, J., \& Svozil, Z. (1999). Pohybová aktivita a sportovní zájmy mládeže. Olomouc: Univerzita Palackého v Olomouci.

Haapala, H., L. (2017). Finnish schools on the move: students' physical activity and school-related social factors (Disertation thesis). Available from: https://jyx.jyu.fi/bitstream/handle/ 123456789/55965/3/978-951-790-442-1_Haapala_.pdf

Jůva, V., \& Svobodová, J. (1996). Alternativní školy. Brno: Paido.

Kalman, M., Hamř́k, Z., \& Pavelka, J. (2009). Podpora pohybové aktivity pro odbornou veřejnost. Olomouc: ORE-institut.

Kenyon, D., B., Kubik, M. Y., Davey, C., Sirard, J., \& Fulkerson, J. A. (2012). Alternative high school students' physical activity: role of self-efficacy. American journal of health behavior, 36(3), 300-310.

Machová, J., Kubátová, D., et al. (2009). Výchova ke zdraví. Praha: Grada.

Mužík, V., \& Vlček, P. (2010). Škola, pohyb, zdraví. Brno: Masarykova univerzita

Národní zpráva o pohybové aktivitě dětí a mládeže. (2018). Olomouc: Fakulta tělesné kultury.

Průcha, J. (2012). Alternativní školy a inovace ve vzdělávání. Praha: Portál.

Rýdl, K. (2001). Peter Petersen a pedagogika jenského plánu. Praha: ISV.

Sigmund, E., \& Sigmundová, D. (2011). Pohybová aktivita pro podporu zdraví a dětí a mládeže. Olomouc: Univerzita Palackého v Olomouci.

Sigmundová, D., \& Sigmund, E. (2015). Trendy v pohybovém chování českých dětí a adolescentů. Olomouc: Univerzita Palackého v Olomouci.

Sobo, EJ. (2013). High Physical Activity Levels in Waldorf/Steiner Education Reflect Alternative Developmental Understandings. Education and Health. 3(1), 26-30.

Svobodová, J. (2007). Výběr z reformních i současných edukačních koncepcí. Brno: MSD.

Tröndle, P. (2008). Wellness: Domácí rozmazlování. Praha: Grada. 
Tudor-Locke, C., Lee, S. M., Morgan, C. F., Beighle, A., \& Pangrazi, R. P. (2006). Children's PedometerDetermined Physical Activity during the Segmented School Day. Medicine \& Science in Sports \& Exercise, 38 (10), 1732-1728.

Tudor-Locke, C., Craig, C. L., Beets, M. W., Belton, S., Cardon, G. M., Duncan, S., Hatano, Y., Lubans, D. R., Olds, T. S., Raustorp, A., Rowe, D. A., Spence, J. C., Tanaka, S., \& Blair, S. N. (2011). How many steps/day are enough? for children and adolescents. The international journal of behavioral nutrition and physical activity, 8, 78.

\section{Contacts:}

Dita Culková

Department of Physical Education and Sports, Faculty of Education,

University of Hradec Králové, Rokitanského 62, 50003 Hradec Králové, Czech Republic

\section{Veronika Procházková}

Primary and Pre-primary Education, Faculty of Education,

University of Hradec Králové, Rokitanského 62, 50003 Hradec Králové, Czech Republic

Jan Suk

Department of English Language and Literature, Faculty of Education,

University of Hradec Králové, Rokitanského 62, 50003 Hradec Králové, Czech Republic

Mgr. Dita Culkova, Ph.D. is an assistant professor at the Department of Physical Education and Sport, Faculty of Education, University of Hradec Králové, where she teaches Physical Education to future nursery and primary school teachers. She obtained her doctoral degree from Kinanthropology and undertook psychotherapeutic training in Integrative Psychotherapy. She specializes in sensation-seeking pedagogy, physical education didactics, Psychomotorics, sport psychology, sport and movement activities, and finally, outdoor sports. Furthermore, she teaches Physical Education at elementary school focused on the Jena Plan school programme. Her specialisation is free time programmes for parents and children.

Mgr. Jan Suk, Ph.D. teaches at the Department of English Language and Literature, Faculty of Education, University of Hradec Králové. Jan Suk took his PhD at Faculty of Arts, Charles University, Prague. His dissertation thesis examined the rich practice of contemporary British experimental theatre Forced Entertainment via Deleuzoguattarian prism. His monograph called The Poetics of Immanence: Performance Theatre of Forced Entertainment is being published at De Gruyter Publishing House in 2019. He has lectured internationally, e.g. at Stanford University, King's College in London or SAIC Chicago. His most recent research interests include performance and/as pedagogy or proximity and/of performance theatre. 